\title{
Mapping of Management Model for Business Incubator
}

\author{
Andreia de Bem Machado ${ }^{1}$, Andreza Regina Lopes da Silva ${ }^{2}$ \\ Carlos Eduardo Negrão Bizzotto ${ }^{3}$
}

${ }^{.}$Doctoral student at the Graduate Program in Engineering and Knowledge Management, in the Media and Knowledge search line. Master in Science Education and Technology from the Universidade Federal de Santa Catarina (UFSC)in 2007. Expert in Literacy also by the UFSC, in 1998. Graduated in Pedagogy in UDESC, in 1994. She is currently a researcher and guiding teacher of the Specialization CourseLato Sensuin Teaching in Educational Media, in the Science Teaching Course and in the Education for Diversity Course with an emphasis on adult education. Research line: virtual environment of teaching and learning, distance education, new technologies, communication

${ }^{2} \mathrm{PhD}$ and Master in Engineering and Knowledge Management at the Federal University of Santa Catarina (UFSC). Administrator by UFSC in 2002. Specialist in Distance Education by SENAC in 2010. Experience in the area of Education with an emphasis on Distance Education working mainly in the subjects: didactic material, project, planning, development, implementation and evaluation of the courses The distance. The different activities developed focus mainly as instructional designer, project coordinator and production of didactic material in EaD. She is currently a researcher at CNPq / UFSC, an EAD project manager and author of chapters on books and scientific articles.

${ }^{3}$ He has a degree in Chemical Engineering from the State University of Maringá (1987), a Master's degree in Production Engineering from the Federal University of Santa Catarina (1992) and a PhD in Production Engineering from the Federal University of Santa Catarina (2002). He participated in the design and implantation of the Blumenau Software Hubs Blusoft (1993), the Blumenau Regional University Foundation - FURB (1996) and the Gene-Blumenau Institute (2002). Was he president of the Catarinense Network of Incubators RECEPET (2001-2006). . He is currently Coordinator of Projects of the National Association of Entities Promoting Innovative Enterprises - ANPROTEC, InfoDev / World Bank accredited consultant in incubation of companies and technical consultant in the Center of Innovative Entrepreneurship of CERTI Foundation.

\begin{abstract}
Management models are grounded in three basic pillars: people, processes and technologies. In this scenario, management model is fundamental for business incubators to be able to meet the demands of new entrepreneurs in different areas of their business developments. Therefore, the objective of this article is to map the management models of business incubators both nationally and internationally. For that, the methodology used was integrative review of the literature using the Scopus database and regulations, international and national documents.As result, a limitation has been identified in the models found as they describe the business incubator as a transformation mechanism without making explicitly better management practices for the continuous improvement of the incubated enterprises.
\end{abstract}

Keywords: incubator, management, innovation.

\section{Introduction}

Alternation in the economy is observed since the 1970s, where consecutive changes provided a model of socio-economic development characterized by a dynamic and competitive scenario.It is noticed that the internationalization of the economy has been heated in recent years by technological development of means of production, making them more efficient and productive, so the traditional production factors are being replaced by a new archetype. In the late 1970s and early 1980s, a period of recession and oil crisis, the economic setting was marked by market opening and a decrease in production activities, which marked a scenario of recession and lack of job opportunities.

In Brazil, from the 1990s, there was a growth in economic development linked to policies based on the formation of a national innovation context, with greater attention given to small and medium business, as generators of jobs and increase of income. The potentiality of innovation, highlighted in Brazil since the 1990s, had direct relationship with the world's economic and social growth.It is noted that the economically developed countries spread the culture of entrepreneurship and innovation through the interactions promoted by the triple helix, a relationship of integration of universities, companies and government, three segments considered innovation agents (LEITE; MORAES, 2016).

In Brazil, a developing country, the need for investment in technological innovation is urgent through the partnerships between the mentioned agents.In order to provide such economic growth it is necessary to boost the growth of innovative small and medium-sized business through their interactions with the public sector and also with universities. According to some authors (ETZKOWITZ; LEYDESDORFF, 2001; SBRAGIA et al., 2005; CLARIM; SOUZA; JANUZZI, 2010), these exchanges take place within the context of the Innovation 
Habitats (IH).Innovation habitats are also known as ecosystems of innovation ${ }^{1}$, that is, a concept that works with interdependence issues, where the success of an innovation depends on the interaction between different actors of the organizational-ecosystem (ADNER; KAPOOR, 2010).

Therefore, the objective of this article is to map the management models of business incubators both nationally and internationally.To do so, the article is organized in five sections. The first is this, entitled introduction.In the second section, the methodological procedures.In the third section, it is described the main concepts of incubator, management model for business incubator, as well as the incubator models of companies in the world and national scenario, from the result of integrative search.In the fourth section the final considerations are made explicit.And finally, listed in the fifth section are the references used to construct this article.

\section{Methodological Procedures}

The methodological procedures used are based on an integrative review, which is a method that provides the synthesis of knowledge and the incorporation of the applicability of results of significant studies in practice (SOUZA; SILVA; CARVALHO, 2010). The integrative review aims to synthesize the results obtained in a specific research on a subject, in a systematic, broad and organized way. This revision is intended to bring together and integrate the knowledge produced on management model for business incubator.To do so, the following steps were performed:the research question was first developed; then the research objective was defined so that the study sample based on the presented results was selected. To guide the research, a question was asked: What are the existing management models nationally and internationally for business incubators? To answer this question, a search was performed in February of 2017 for indexed publications in the online database Scopus, an impact database of peer-reviewed scientific literature with an interdisciplinary feature which contributes to a broad view of scientific publications (SILVA; MACHADO; CATAPAN, 2014, p. 6).

The descriptors used in the first search were "Business incubator management model *".A second search with the term "Management model for company incubator*" and a third search "Management model for company incubator" OR "management model for business incubator". It should be noted that a time period restriction was not established.The "*" (asterisk), truncation element, was used to restore variations of a term and the "" (quotation marks) was used as a resource to get the exact expression. Studies that addressed the management model theme for business incubatorswere selected with inclusion criteria for analyzing this research.As exclusion criteria, studies that did not present abstracts in full in the databases or with free access on the web were disregarded. It should be noted that the search was carried out in an orderly manner, respectively, Scopus and with the integration of regulations, international and national documents contained in the Associação Nacional de Entidades Promotoras de Empreendimentos Inovadores- ANPROTEC (National Association of Entities Promoting Innovative Enterprises). The publications that were indexed in more than one of the databases were selected on the first search. The review, using the Scopus database, originated the synthesized result in Table 1, where 78 documents were identified in the first search, 34 in the second and 18 in the last.

\begin{tabular}{|c|c|c|c|}
\hline \multicolumn{4}{|l|}{ Scopus database } \\
\hline Search terms & $\begin{array}{l}\text { Business incubator } \\
\text { management model* }\end{array}$ & $\begin{array}{l}\text { Management model for company } \\
\text { incubator* }\end{array}$ & $\begin{array}{lrr}\text { Management } \quad \text { model for } \\
\text { company incubator } \\
\text { management model for business } \\
\text { incubator }\end{array}$ \\
\hline Search fields & $\begin{array}{l}\text { title”, "abstract", "keywo } \\
\text { rd"” }\end{array}$ & "title", "abstract”, "keyword" & title”, "abstract", "keyword" \\
\hline $\begin{array}{l}\text { Total of recovered } \\
\text { documents }\end{array}$ & 78 & 34 & 18 \\
\hline Selected articles & 48 & 19 & 13 \\
\hline Areas of knowledge & 13 & 10 & 7 \\
\hline Publication types & 7 & 5 & 3 \\
\hline
\end{tabular}

Table 1 - Systematic results of the Scopus search

Source: Authors (2017)

After the complete reading of the selected articles, using the previously defined criteria, Table 2 with the integrator summary of results was generated.

\begin{tabular}{l|l} 
Term used in the search & Abstract
\end{tabular}

${ }^{1}$ Term used to describe a wide and diversified array of participants and resources that contribute to the
generation of an entrepreneurial environment and innovations. This includes entrepreneurs, investors,
researchers, innovation environments (incubators, parks, accelerators, co-working, among others), instances of
governments, etc.(ANPROTEC, 2016, p. 7). DOI: $10.9790 / 487 X-1905052834 \quad$ www.iosrjournals.org $\quad 29 \mid$ Page 


\begin{tabular}{|l|l|}
\hline Business incubator management model* & $\begin{array}{l}\text { The articles clearly state on the development of the theory of business incubation, the } \\
\text { management model based on management practice and the formulation of policies } \\
\text { for the management of incubators.Are also made explicit best practices and these } \\
\text { require a holistic approach, where the goals of the incubators are taken into } \\
\text { account.There are also articles that examine the innovation management, considered } \\
\text { one of the most representative factors of competitiveness of companies. The concept } \\
\text { of collective innovation is addressed, which deals with the formation of networks of } \\
\text { business incubation.It also makes explicit the importance of knowledge management } \\
\text { in the business incubator management model to ensure that appropriate culture and } \\
\text { strategies lead to increased knowledge creation. }\end{array}$ \\
\hline $\begin{array}{l}\text { Management model for company } \\
\text { incubator* }\end{array}$ & $\begin{array}{l}\text { The articles explain about types of incubator, network incubator, organizational } \\
\text { model and entrepreneurship.It also explains the resource-based view by examining } \\
\text { and explaining the varieties of resource dimensions. These articles also explain a } \\
\text { theoretical approach based on the development of the dynamic knowledge networks } \\
\text { model. }\end{array}$ \\
\hline $\begin{array}{l}\text { Management model for company } \\
\text { incubator or management model for } \\
\text { business incubator }\end{array}$ & $\begin{array}{l}\text { The articles are the same as those found in the review carried out as the theme } \\
\text { management model for company incubator*, therefore they were disregarded from } \\
\text { the study. }\end{array}$ \\
\hline
\end{tabular}

Source:Authors (2017)

Table 2 - Integrative Summary

The articles found in the search explain a model of dynamic knowledge networks, but do not emphasize how the implementation of this model would be.From this result and the integration with other references used to systematize this research, a conceptual analysis of incubators is described below.

\section{Incubators}

In the innovation scenario, IHs have a great relevance for the regional development and economic growth, since they constitute the mediation of knowledge, productive practices and interactions between companies, universities and government agents.However, one of the great challenges of the innovation scenario is to create a structure for companies to build the knowledge necessary for their growth and their stay in the competitive market.

According to the Ministério da Ciência, Tecnologia, Inovações e Comunicações- MCTIC (Ministry of Science, Technology, Innovations and Communications), Brazil has a high mortality rate in the first four years of business existence, with a mortality rate of up to $59.9 \%$ (MCTI, 2014).

The explanation is due to the fact that most Brazilian entrepreneurs are not prepared for the highly competitive market (WILLIAMS; YOUSSEF, 2013). It is perceived that the companies are created by necessity and not by identifying an opportunity to undertake.Thus, it is common for business to be created by people who have lost their jobs or those who need to raise their family's income (GEMA, 2013).

In this context, appear the business incubators that support the entrepreneurs of identification and selection of opportunities for the generation of new innovative successful ventures.

According to ANPROTEC (2016) Brazil has 369 incubators in operation, housing 2.310 incubated companies and 2.815 graduated companies, generating 53.280 jobs.The turnover of companies supported by incubators exceeds $\mathrm{R} \$ 15$ billion. Regarding the activity aspect, 55\% of incubators of Brazilian companies are technological, $19 \%$ are traditional, $18 \%$ are mixed and $8 \%$ are other types.

Considering the growth of the last 10 years of business incubation development, the reality shows that half of the Brazilian incubators are up to 8 years of age, concentrated in the range of 3 to 5 years and have their income from management and public entities.

There is a great variety and multiplicity of the internal functions of the incubators, intensifying the importance of a taxonomy based on functions, strategies and objectives (ANPROTEC 2012).

It is also noticed that the main problems are the lack of qualification of the professionals responsible for the management of the incubator and support to incubated companies, which has make it difficult to raise money and also the harmony with the region's innovation ecosystems.

It is observed that the movement of incubators in the Brazilian scenario has been growing significantly since 1990. This has been due to the actions carried out by ANPROTEC, which through partnerships carry out initiatives that favor the planning of incubators, the training of managers, as well as the creation of reference centers, with the purpose of establishing management models for business incubators.

Therefore, in 2006, ANPROTEC created the reference management model for business incubators, called CERNE (Center of Reference for Support to New Ventures), which aims to improve qualitatively and quantitatively the results of Incubators.

This model of good management practices is in line with what has been classified as a "third-generation Incubator".First-generation incubators (from the late 1950s to the 1980s) emphasized physical and technological infrastructure as a way of supporting the development of new, innovative ventures. 
Second generation incubators (1980 to 1990) also offered physical and technological infrastructure, but focused on offering business development services.

From the 1990s, the third-generation incubators have emerged, focusing on networking.The incubators that implant the CERNE model are aligned with strategies, processes and services of the third generation incubators. This management reference model, as Cardoso et. al. said.(2008) has its principles and values based on quality management systems, encouraging the participation of all its members to achieve long-term success, through customer satisfaction, and benefits for the organization and for society.

CERNE, as a reference management model for business incubators, is a national model, based on the context and reality of Brazil.This model proposes the key processes and practices that an incubator must possess to systematically generate innovative and successful ventures. The goal of the CERNE Model is to expand the number of successful ventures developed in incubators through a platform of assistance and solutions. Thus, the risks of failure to generate new business are minimized, since the processes used are systematized (ANPROTEC, 2012).

\subsection{Management model for business incubator}

Business incubators are a type of innovation habitat, spaces with physical, technological and service infrastructure to support the process of generation and development of new business.

Incubators support ventures in which the main purpose results in innovation.

The term "incubator" is related to the care provided in the process of a company being born, defined by Law \# 13.243 as.

III - A - business incubator: organization or structure that aims to stimulate or provide logistical, managerial and technological support to innovative and knowledge-intensive entrepreneurship, with the objective of facilitating the creation and development of companies that have as a differential the performance of activities focused on innovation [...](BRAZIL, 2016).

Biaggio (2006) defines the types of incubators by classifying them according to the incubation process, purpose of the incubator and types of companies supported, as shown in Table 3 below:

\begin{tabular}{|l|l|l|}
\hline Incubation process & Purpose of incubator & Types of businesses supported \\
\hline $\begin{array}{l}\text { Physical incubation; Distance Incubator } \\
\text { and Virtual Incubator. }\end{array}$ & Sectorial Incubator and Social Incubator & $\begin{array}{l}\text { Agribusiness incubator; } \\
\text { Cultural incubator; Arts incubator; } \\
\text { Technology-based business incubator; }\end{array}$ \\
& & $\begin{array}{l}\text { Business incubator of traditional sectors; } \\
\text { Mixed incubator }\end{array}$ \\
\hline
\end{tabular}

Source: Biaggio (2006)

Table 3 - Types of incubators

Based on the incubation process, incubators can be classified as "physical incubation" (when entrepreneurs occupy a physical space in the incubator), "distance incubation" (business are supported by the incubator, but are not physically installed in the incubator) and "virtual incubation" (support for e-commerce business, which receives services and support from virtual incubators through the internet). As for the purpose, the incubator can be sectoral (they house companies of only one sector of the economy), social (they house projects originated from social projects) and traditional sectors (that meet the demand of income and job creation and also the improvement in the economic conditions of the community). Regarding the type of business supported, we can explain:Agribusiness incubator are organizations that hold enterprises linked to agricultural services; Cultural incubator, organizations that foster entrepreneurship linked to culture; Incubators of cooperatives, support cooperatives in process of training, presenting as a process ofdistance incubation, with the purpose of creating jobs and income for within or near the municipality; technology-based incubators are ventures that house product, process and service companies that are the result of scientific research; Incubators from traditional sectors are interconnected to sectors of the economy originated from technology.Mixed incubator, those housing technology-based companies and traditional sectors. According to ANPROTEC (2012), there are different types of incubators that are classified as: technology-based (those housing technology-intensive business); Traditional (those that support companies from traditional sectors of the economy); Mixed (Both technology-based and traditional sectors) and Social (targeting cooperatives and popular associations). The development of management models for business incubators has been developed since 1985, and in the systematic search conducted in the literature review, the first article on this theme dates back to 1988. Based on this search, it was observed that some 17 management models for business incubators have already been created, shown in Table 4 below: 


\begin{tabular}{|c|c|c|c|}
\hline Year & Author & Purpose of the Model & Type of Model \\
\hline 1985 & $\begin{array}{|lll|}\begin{array}{l}\text { Campbell, } \\
\text { Samuelson }\end{array} & \text { Kendrick } \quad \& \\
\end{array}$ & $\begin{array}{l}\text { Demonstrate the main value-adding activities of } \\
\text { the incubator }\end{array}$ & Structure model \\
\hline 1987 & Smilor & $\begin{array}{l}\text { Show that the business incubator is a } \\
\text { transformation mechanism in which industry, } \\
\text { government, and university are interrelated }\end{array}$ & Structure model \\
\hline 1988 & Nijkamp & $\begin{array}{l}\text { Analyze the incubators and reveal the structural } \\
\text { components of the same. }\end{array}$ & Structure model \\
\hline 2000 & Carter \& Jones -Evans & Identify key step to the incubation process. & Process model \\
\hline 2000 & Nowak \& Grantham & $\begin{array}{l}\text { Propose the creation of a virtual incubation } \\
\text { model. }\end{array}$ & Structure model \\
\hline 2000 & Booz, Allen \& Hamilton & Introduce a corporate business incubator model & Process model \\
\hline 2002 & Lazarowich \& Wojciechowski & Describe an "incubator of new economy" & Structure model \\
\hline 2002 & Costa-David, Malan, Lalkaka ${ }^{2}$ & $\begin{array}{l}\text { Provide guidance to the States for the } \\
\text { incubation process. }\end{array}$ & Mixed model \\
\hline 2003 & Gibson, Wiggins. & $\begin{array}{l}\text { Introduce a model for incubator technology } \\
\text { companies. }\end{array}$ & Structure model \\
\hline 2004 & Sahay & $\begin{array}{l}\text { Demonstrate the main building blocks of } \\
\text { business incubator }\end{array}$ & Structure model \\
\hline 2004 & Hackett \& Dilts & $\begin{array}{l}\text { Present the main inputs and results of the } \\
\text { incubation process.Consider the incubator as a } \\
\text { facilitating technology, rather than a critical or } \\
\text { strategic technology }\end{array}$ & Structure model \\
\hline 2004 & Hackett \& Dilts, Peters & $\begin{array}{l}\text { Explain key processes in the production } \\
\text { process of an incubator }\end{array}$ & Process model \\
\hline 2008 & Bergek, Norrman & $\begin{array}{l}\text { Develop a business incubation model that will } \\
\text { focus on results, on the one hand, and work } \\
\text { with the uncertainty on the other. }\end{array}$ & Process model \\
\hline 2009 & InfoDev(World Bank) & $\begin{array}{l}\text { Linking the business incubation process to the } \\
\text { business life cycle }\end{array}$ & Process model \\
\hline 2010 & Jones & Present an incubation value chain & Process model \\
\hline 2011 & Chandra \& C.-A. Chao & $\begin{array}{l}\text { Show a flow of resources (money and } \\
\text { technology) in the innovation ecosystem }\end{array}$ & Process model \\
\hline 2012 & Metibtikar $^{3}$ & Map the incubator processes & Process model \\
\hline
\end{tabular}

Table 4: Management model for business incubator

Source: Authors (2017)

\subsubsection{Management model for business incubator in Brazil}

In Brazil, there is a lack of references on management models for business incubators.Among the existing models we can explain two of them:Management model implemented at the Instituto Genesis in Rio de Janeiro and CERNE Model. The management model of the Instituto Genesis is based on the principle of continuous improvement, based on the PDCA cycle (PLAN - DO - CHECK - ACT).Accordig to Aranha (2002) the model is composed of five stages, namely: planning; execution; monitoring and control; corrective action; and information.Its operation is based on processes, and these happen at different levels of the incubator.In 2015 the Instituto Genesis was certified as CERNE Incubator.

The CERNE model is a national model, so it will be more discussed in this article.Proposed by ANPROTEC in partnership with SEBRAE (Serviço Brasileiro de Apoio às Micro e Pequenas Empresas Brazilian Service of Support to Micro and Small Enterprises), this model uses a methodology to identify systems, elements and key practices that an incubator must implement to generate successful business.

In this sense, a reference model was developed to support entrepreneurship, with the objective of "promoting a quantitative-qualitative leap for business incubators in different areas" (ANPROTEC, 2013).

This model aims to provide incubators with a maturity that makes them capable of systematically generating successful business (ANPROTEC, 2013). According to this model, the incubator must act in three independent and complementary dimensions: development, process and incubator:

i. Development: this level includes the processes directly related to the generation and development of the enterprises, that is, the focus is on practices that help improve products, services and technologies, access to capital, market participation, effective management, and the personal development of entrepreneurs.

\footnotetext{
${ }^{2}$ Centre for Strategy \& Evaluation Services. Benchmarking of Business Incubators. European Commission Enterprise Directorate General: Brussels.2002.

${ }^{3}$ GADEA, Eloy Sentana. Rentabilidad económica y social de los viveros de empresas de la Comunidad Valenciana: durante el periodo 2004-2014. 2016. 675 f.Thesis (Doctorate) - Curso de Facultad de Económicas, Departamento de Organización de Empresas, Universidad de Alicante, Espanha, 2016. Available at: $<$ https://rua.ua.es/dspace/bitstream/10045/55627/1/tesis_eloy_sentana_gadea.pdf $>$.Accessed on: March 9th 2017 
ii. Process: the focus of this level is on the processes that enable the transformation of ideas into ventures.

iii. Incubator: the focus of the processes of this level is the management of the incubator as an enterprise and the extension of its limits, that is, the processes related to finances, people and the relationship of the incubator with the surroundings.

The CERNE Model proposes four levels of maturity, each has a specific focus:

- CERNE 1 - Development: in this first level, all processes and practices are directly related to the development of the enterprises.In this sense, in addition to processes such as planning, qualification, consultancy, selection and monitoring, practices directly linked to the incubator management were included, which, in turn, have a very close relationship with the development of enterprises, such as financial management and management of physical and technological infrastructure.By implementing this level, the incubator demonstrates that it has the ability to prospect and select good ideas and turn them into successful innovative business, systematically and repeatedly.

- CERNE 2 - Incubator: the focus of this level is to ensure effective management of the incubator as an organization.Thus, the incubator must implement processes that enable its strategic management, the expansion of services provided and target audience and the evaluation of its results and impacts.

- CERNE 3 - Network of Partners: the objective of this level is to consolidate a network of partners, aiming to broaden the performance, creating capable and effective instruments to carry out distance incubation.Thus, at this level, the incubator reinforces its performance as one of the "us" of the network of actors involved in the process of promoting innovation.

- $\quad$ CERNE 4 - Internationalization: at this level, based on the structure implemented at previous levels, the incubator has enough maturity to consolidate its international positioning, implementing practices that support companies incubated or graduated in the internationalization process.

The CERNE model is currently being implemented in 108 Brazilian incubators, and in 2016 the following incubators were awarded the CERNE 1 certification:

- Arca Multincubadora (Cuiabá - MT)

- $\quad$ Centro de Empreendedorismo e Incubação (CEI - Porto Alegre - RS);

- Centro Empresarial para laboração de tecnológicas Avançadas (Celta - Florianópolis - SC);

- Centro Incubador Tecnológico (CIT - Cascavel - PR);

- Incubadora Raiar (Porto Alegre - RS);

- Incubadora Tecnológica Natal Central (ITNC - Natal - RN);

- Incubadora Tecnológica Softville (Joinville - SC);

- $\quad$ Instituto Empresarial de Incubação e Inovação Tecnológica (IEITEC - Canoas - RS);

- Instituto Gene Blumenau

- MIDI Tecnológico (Florianópolis - SC);

- $\quad$ Núcleo de Incubação do Porto Digital (Recife - PE);

\section{Final Considerations}

The integrative review carried out to meet the objective of this research is only starting, but it has already allowed to identify that a management model based on management practice and policy formulation for the management of incubators is explicit, but the formulation for the implementation of best practices is not explicit in the incubation process.

One of the problems found in these models is that most management models for business incubators describe an incubator as a transformation mechanism. The entrepreneur and / or business idea are inputs to the business incubation system and in this sense it is considered important to develop and make explicit practices to increase the performance of the incubation system.

However, it is noticed that few models described the incubation process in detail, explain which services should be applied in the specific conditions and cases of each region where the incubator is located. The models emphasize selection and admission procedures as one of the most important in the incubation process.There are no clear guidelines on how to measure the effectiveness and efficiency of the incubation process, what performance metrics to use (growth and financial performance at the time of leaving the incubator etc.). Based on this review, it can be seen that there is no model that has linked the entrepreneur's life cycle, incubation process and processes in the innovation ecosystem (external environment). No model describes the importance of cultural issues for incubation performance. The business incubation program should be considered as a cultural transformation mechanism. Also there is no model that proposes the implementation of knowledge management within the incubation process

The mapping developed here allows us to verify that incubator management is an intensive activity in knowledge and requires continuity of study highlighting practices to socialize, outsource, share and internalize the knowledge developed in this innovation environment. Proposes for future work the study of the implementation of knowledge management so that the incubators potentiate the development of their incubates. 


\section{References}

[1]. ADNER, R.; KAPOOR, R. Value creation in innovation ecosystems: how the structure of technological interdependence affects firm performance in new technology generations. Strategic Management Journal, 31, 306-333. 2001. Available at:http://dx.doi.org/10.1002/smj.821.Accessed on: February 18th 2017.

[2]. ANPROTEC. CERNE: Centro de Referência para Apoio a Novos Empreendimentos. 2013. Available at: <http://anprotec.org.br/cerne/>. Accessed on: February13th 2017.

[3]. ANPROTEC. Available at: <http://www.anprotec.org.br/publicacao.php?idpublicacao=1018>. Accessed on: February 20 th 2017.

[4]. ANPROTEC..=Estudo de Impacto Econômico Segmento de Incubadoras De Empresas Do Brasil. 2016. Available at: http://www.anprotec.org.br/Relata/18072016\%20Estudo_ANPROTEC_v6.pdf. Accessed on: February 13th 2017.

[5]. ARANHA, José Alberto Sampaio et al. Modelo de gestão para incubadoras de empresas-implementação do modelo. Rede de Tecnologia do Rio de Janeiro. Rio de Janeiro. 2003.

[6]. BERGEK, A.; NORRMAN, C. Incubator best practice: a framework. Technovation, 28(1-2), p. 20-28. 2008.

[7]. BIAGIO, L. A. Incubadora de empreendimento orientado para o desenvolvimento local e setorial: planejamento e gestão e operação. Brasília: ANPROTEC, 2006.

[8]. BRAZIL. Law \# 13.243. Provides incentives for scientific development, research, scientific and technological training and innovation, 2015. Diário Oficial da União, Brasília, January 11th 2016.

[9]. CAMPBELL, C.; KENDRICK, R.; SAMUELSON, D. Stalking the Latent Entrepreneur. Economic Development Review, Vol. 3, No. 2, pp. 43-48. 1985.

[10]. CARDOSO, Rodolfo; SPIEGEL, Thaís; CAULLIRAUX, Heitor; PROENÇA, Adriano. Uma investigação do uso de modelos de referência para a construção de modelos de gestão. Anais XXVIII, ENEGEP, Rio de Janeiro, 2008.

[11]. CARTER, S. \& JONES-EVANS, D. Enterprise and Small Business: Principles, Practice and Policy, Pearson Education Ltd, Harlow, England.2000

[12]. CENTRE FOR STRATEGY \& EVALUATION SERVICES. Benchmarking of Business Incubators. European Commission Enterprise Directorate General: Brussels.2002.

[13]. CHANDRAa, A.; CHAO, C.A. (2011). Growth and evolution of high-technology business incubation in China. Human Systems Management 30, 55-69.

[14]. CLARIM, H.; SOUZA, C.; JANNUZZI, A. Gestão tecnológica e empreendedorismo: o modelo da hélice tripla em institutos de pesquisa alavancando a inovação. COBENGE - Brazilian Congress of Engineering Education, Fortaleza, September 2010.

[15]. ETZKOWITZ, H.; LEYDESDORFF, L. The triple helix of university-industry-government relations and the globalization of national systems of innovation. Science under Pressure Proceedings, The Danish Institute for Studies in Research and Research Policy, 2001.

[16]. GADEA, Eloy Sentana. Rentabilidad económica y social de los viveros de empresas de la Comunidad Valenciana: durante el periodo 2004-2014. 2016. 675 f.Thesis (Doctorate) - Curso de Facultad de Económicas, Departamento de Organización de Empresas, Universidad de Alicante, Espanha, at: <https://rua.ua.es/dspace/bitstream/10045/55627/1/tesis_eloy_sentana_gadea.pdf>. Accessed on:February 9 th 2017.

[17]. HACKETT, S. M.; DILTS, D. M. A Real Options-Driven Theory of Business Incubation. The Journal of Technology Transfer, v. 29, n. 1, p. 41-54. 2004.

[18]. HACKETT, S. M. \& DILTS, D. M.. A Systematic Review of Business Incubation Research. The Journal of Technology Transfer, v. 29, n. 1, p. 55-82. 2004.

[19]. INFODEV. Available at: http://www.infodev.org/highlights/infodev-2009-annual-report-published. Accessed on:February 20th 2017.

[20]. LALKAKA, R.; BISHOP, J. Business incubators in economic development: an initial assessment in industrialising countries. Nova Iorque: United Nation Development Programme, 1996.

[21]. LEITE, Y. V. P.; MORAES, W. F. A. The ability to innovate in international entrepreneurship. Rev. Adm. (São Paulo) [online], v. 50, n. 4, 2015, p. 447-459. Available at: <http://ref.scielo.org/vhz9hg>. Accessed on:February 4th 2017.

[22]. MCTI. Ministério da Ciência, Tecnologia e Inovação. Business Incubator Manual, Available at:http://www.mct.gov.br/Temas/Desenv/Manual-Incubadoras.pdf. Accessed on: March 3rd 2017.

[23]. NOWAK, M. J.; GRANTHAM, C. E. Virtual Incubator: Managing Human Capital in the Software Industry. Research Policy, v.29, n. 2, p. 125-134.2000.

[24]. Sahay, A. The Role of Technology Business Incubator, Angel Investor, and Venture Capital Fund in Industrial Development 2005.

[25]. SBRAGIA, R. et al. Inovação: como vencer esse desafio empresarial. São Paulo: Clio, 2006.

[26]. SILVA, A. R. L. da; MACHADO, A. B.; CATAPAN, A. H.Contribuição da Comunicação Digital na Educação a Distância um mapeamento bibliométrico. In: Patricia Bieging e Raul Inácio Busarello. (Org.). Interatividade nas TICs: abordagens sobre mídias digitais e aprendizagem. 1ed.São Paulo: Pimenta Cultural, 2014, v. 1, p. 169-189.

[27]. SMILOR, R. W. Managing the Incubator System: Critical Success Factors to Accelerate New Company Development. IEEE Transactions on Engineering Management, Vol. 34, No. 4, pp. 146-156. 1987.

[28]. UBI INDEX. Benchmarking Incubation Globally. 2015. Available at: <www.ubiindex.com>. Accessed on: March 3rd 2017.

[29]. SOUZA, Marcela Tavares de; SILVA, Michelly Dias da; CARVALHO, Rachel de. Revisão integrativa: o que é e como fazer: Integrative review: what is it? How to do it?. Review: einstein, São Paulo, v. 1, n. 8, p.102-105, January 30th 2010. Available at: <http://www.scielo.br/pdf/eins/v8n1/pt_1679-4508-eins-8-1-0102.pdf>. Accessed on: February 4th 2017.

[30]. WILLIAMS, C. C.; YOUSSEF, Y. Avaliando as variações de género no sector informal Empreendedorismo: algumas lições do Brasil, Journal of Developmental Empreendedorismo, v. 18, n.1, p.1-16.2013. 